\title{
Birth Rate in the Northern Russian Regions
}

\author{
Popova LA* and Shishkina MA \\ Department of Socio-Economic and Energy Problems of the North Komi Scientific Centre, Ural Branch of the Russian Academy of Sciences, Russia
}

Submission: November 02, 2017; Published: December 11, 2017

*Corresponding author: Popova LA, Doctor of Economics Institute of Socio-Economic and Energy Problems of the North Komi Scientific Centre, Ural Branch of the Russian Academy of Sciences 26, Kommunisticheskaya Street, Syktyvkar, Komi Republic, 167982, Russian Federation, Russia, Email: popova@iespn.komisc.ru

\section{Introduction}

To the north regions of Russia traditionally consider 13 subjects of Russian Federation, which territories fully belong to the North Zone. Five subjects are located on the European North: republics of Karelia and Komi, Murmansk and Arkhangelsk regions and Nenets Autonomous Okrug. The Asiatic North includes eight subjects: republics of Sakha (Yakutia) and Tuva, Kamchatka, Magadan and Sakhalin regions, Khanty-Mansi, Yamalo-Nenets and Chukotka Autonomous districts. For the most of these regions are characterized the higher level of birth rate than in the average by Russia (Figure 1), that mainly due to incomplete transition to the reduced lifetime fertility. Stable lower birth rate only in Murmansk region and in the separate years in Karelia Republic, Magadan and Sakhalin regions [1].

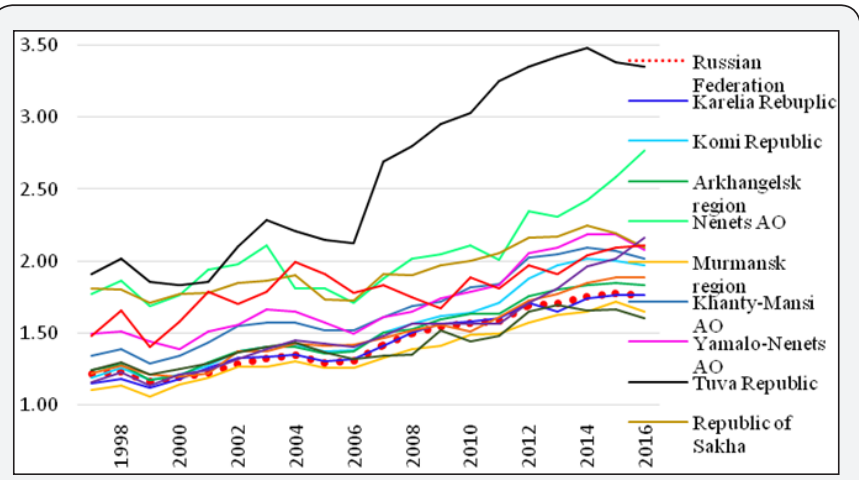

Figure 1: Dynamics of total fertility rate in the northern regions of Russia, children to the one woman for the all fertile period $15-49$ years [1].

Since the beginning of 2000s in the northern regions of Russia, as in a whole by country, after more than ten-years declining observe it's rising. In the first years the increase has been conditioned by two factors. Firstly, by improvement of structure of women in fertile age in consequence of the reach the reproductive ages relatively numerous generations of 1980 s years of the birth. Secondly, by the implementation in the condition of economic growth the births, deferred in the crisis 1990s. In the second part of null years another one factor of birth rate rise appears: the activation of state demographic policy in Russia. Since 2007 to the families, in which was born (was adopted) the second (subsequent) child, began to be paid the maternal (family) capital. In 2007 its amount was 250 thousand rubles, at present time it exceeds 453 thousand rubles.

At the beginning of 2010 s the federal measures of pro-family demographic policy have been strengthened with regional measures: has been introduced regional maternal (family) capital. The size, appointment and spending priorities of regional capital differentiated by the regions. Its size varies in the North from 50 thousand rubles in Arkhangelsk region and Tuva Republic to the 366 thousand rubles in Nenets AO. In the majority of Northern regions the payment is made on the third (subsequent) children. But in Sakhalin region the regional capital is appointed on the second child. In Tuva, characterized the total fertility rate more than three children, it is paid only on the

fifths (subsequent) child. In the Kamchatka region - on the third (subsequent) child, but size of the payment rise with increasing the order of birth. Since 2015 in Magadan and Kamchatka regions and since 2018 in the Sakhalin is paid regional capital when young women (before 25 years) bear first children to prevent the postponement of the firstborns. In all cases families have the right to realize both federal and regional capitals only once, selecting more preferable alternative for themselves.

Federal maternal capital may spend on improvement of housing conditions of the family; education of the children; funded pension of mother; the social adaptation and integration in the society disabled children. The regional capitals have more ways of realization. Almost everywhere in the North it may be spend on medical service, the acquisition of vehicles, snowmobiles, boats, boat motors, that actual for North with it discharged system of the resettlement, on the purchase of agricultural equipments for development of personal farming, on the arrangement of life and personal needs of families. This is more important measures of Russian pro-family demographic policy. Other directions of support the families with children in Russia are described in [2].

With the use of the method of standardization by agespecific birth rates for 2006 , which proceeded to the beginning 
of activation the demographic policy by birth rate stimulating, it was detected, that its measures have enough strong influenced on growth of birth rate intensity [3]. According to our calculations, for 2007-2015 in Russia was born 19,8\% more children, than it might be with saving the intensity of fertility on level 2006, in other words, was happened 3,2 million additional births. On the North the rise of birth rate intensity in whole a few lower: $18,8 \%$. In absolute terms it is 195,6 thousands of children. The maximum increase was in the Tuva Republic $(30,2 \%$ additional births), Komi Republic (20,2\%), Nenets (20,2\%), Khanty-Mansi
$(19,7 \%)$ and Yamalo-Nenets $(18,9 \%)$ autonomous districts. In the northern subjects of The Far-Eastern Federal district, especially in Chukotka AO, the growth of birth rate intensity below, than in European, Ural and Siberian northern subjects (Table 1). In majority of regions it greater in rural territories, where the opportunity of using the maternal capital on the improvement of housing conditions is more reality [4], and payment the allowance to the third child in size of children subsistence minimum to the low income families is a more significant material support to the families with children.

Table 1:

\begin{tabular}{|c|c|c|c|c|c|c|c|c|c|c|c|c|c|c|c|c|c|c|c|c|c|}
\hline $\begin{array}{c}\text { Total } \\
\text { fertility rate }\end{array}$ & & 1998 & & 2000 & & 2002 & & 2004 & & 2006 & & 2008 & & 2010 & & 2012 & & 2014 & & 2016 & \\
\hline $\begin{array}{c}\text { Russian } \\
\text { Federation }\end{array}$ & $\underset{\sim}{\stackrel{\infty}{\sim}}$ & 1.232 & 듬 & 1.195 & $\underset{\sim}{\stackrel{n}{\sim}}$ & 1.286 & $\underset{m}{\sim}$ & 1.344 & 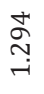 & 1.305 & $\underset{r}{\stackrel{\sigma}{+}}$ & 1.502 & $\underset{\text { ஸे }}{\stackrel{7}{\leftarrow}}$ & 1.567 & 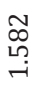 & 1.691 & 동 & 1.75 & 今ิ & 1.76 & $\begin{array}{c}\text { Russian } \\
\text { Federation }\end{array}$ \\
\hline $\begin{array}{l}\text { Karelia } \\
\text { Rebuplic }\end{array}$ & $\stackrel{\text { L }}{\longrightarrow}$ & 1.179 & $\stackrel{\sim}{\sim}$ & 1.178 & $\stackrel{\text { ஸn }}{\stackrel{\sim}{\sim}}$ & 1.326 & $\stackrel{\text { m}}{m}$ & 1.35 & 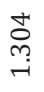 & 1.32 & $\underset{\sim}{\stackrel{\sim}{r}}$ & 1.5 & 華 & 1.577 & 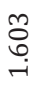 & 1.708 & 䗆 & 1.744 & $\begin{array}{l}\stackrel{0}{2} \\
\stackrel{-}{r}\end{array}$ & 1.76 & $\begin{array}{l}\text { Karelia } \\
\text { Rebuplic }\end{array}$ \\
\hline $\begin{array}{c}\text { Komi } \\
\text { Republic }\end{array}$ & $\stackrel{9}{\rightarrow}$ & 1.26 & 극 & 1.21 & กิ & 1.37 & $\stackrel{+}{-}$ & 1.42 & $\hat{m}$ & 1.38 & & 1.56 & 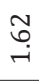 & 1.64 & 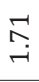 & 1.88 & م્ & 2.02 & $N$ & 1.97 & $\begin{array}{c}\text { Komi } \\
\text { Republic }\end{array}$ \\
\hline $\begin{array}{l}\text { Arkhangelsk } \\
\text { region }\end{array}$ & $\stackrel{\stackrel{+}{\sim}}{\sim}$ & 1.281 & 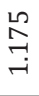 & 1.206 & ণั & 1.375 & 뭉 & 1.405 & ஸ̂م & 1.374 & 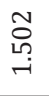 & 1.528 & ஸூ & 1.632 & 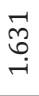 & 1.759 & $\begin{array}{l}\text { n̊ } \\
\stackrel{\infty}{-1} \\
-i\end{array}$ & 1.835 & 令 & 1.83 & $\begin{array}{l}\text { Arkhangelsk } \\
\text { region }\end{array}$ \\
\hline Nenets AO & $\stackrel{N}{\stackrel{N}{-}}$ & 1.866 & 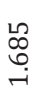 & 1.766 & ‡్丶 & 1.977 & $\stackrel{ }{i}$ & 1.809 & 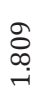 & 1.707 & $\underset{\substack{0 \\
\infty}}{\substack{+i}}$ & 2.018 & 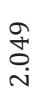 & 2.109 & $\begin{array}{l}\hat{o} \\
\text { o } \\
\text { i }\end{array}$ & 2.345 & $\stackrel{\sim}{\overparen{n}}$ & 2.423 & $\begin{array}{l}\stackrel{+}{\infty} \\
\stackrel{\leftrightarrow}{N} \\
\text { in }\end{array}$ & 2.77 & Nenets AO \\
\hline $\begin{array}{l}\text { Murmansk } \\
\text { region }\end{array}$ & $\stackrel{-}{-}$ & 1.137 & 후 & 1.14 & $\begin{array}{l}\infty \\
\stackrel{\infty}{\infty} \\
\stackrel{\sim}{\rightarrow}\end{array}$ & 1.268 & $\begin{array}{l}\infty \\
\stackrel{\infty}{0} \\
\stackrel{\sim}{\sim}\end{array}$ & 1.305 & 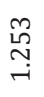 & 1.256 & $\underset{\sim}{m}$ & 1.387 & $\underset{+}{\stackrel{+}{+}}$ & 1.486 & 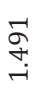 & 1.569 & $\underset{\sim}{\stackrel{n}{\sigma}}$ & 1.649 & $\underset{\sim}{\stackrel{+}{\sim}}$ & 1.65 & $\begin{array}{l}\text { Murmansk } \\
\text { region }\end{array}$ \\
\hline $\begin{array}{l}\text { Khanty- } \\
\text { Mansi AO }\end{array}$ & $\stackrel{\text { ঙे }}{\text { m }}$ & 1.386 & $\stackrel{\text { กิ }}{-}$ & 1.339 & $\underset{\sim}{\stackrel{\vec{q}}{+}}$ & 1.545 & ํㅗㄱ & 1.575 & 룰 & 1.517 & 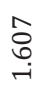 & 1.683 & $\underset{\sim}{\stackrel{\sim}{\sim}}$ & 1.814 & $\begin{array}{l}\infty \\
\infty \\
\infty \\
\stackrel{-}{+}\end{array}$ & 2.023 & $\begin{array}{l}\text { L } \\
\text { N } \\
\text { ㄱ. }\end{array}$ & 2.09 & 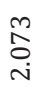 & 2.02 & $\begin{array}{c}\text { Khanty-Mansi } \\
\text { AO }\end{array}$ \\
\hline $\begin{array}{c}\text { Yamalo- } \\
\text { Nenets AO }\end{array}$ & ন্ণ & 1.512 & $\underset{+}{\stackrel{+}{i}}$ & 1.384 & 오 & 1.554 & 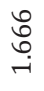 & 1.649 & ำ & 1.498 & $\begin{array}{l}0 \\
\text { Oे } \\
0 \\
\end{array}$ & 1.652 & $\underset{\stackrel{m}{\leftarrow}}{\stackrel{\sim}{\leftarrow}}$ & 1.785 & $\begin{array}{l}\infty \\
\infty \\
\infty \\
\stackrel{-}{-}\end{array}$ & 2.053 & $\stackrel{g}{\circ}$ & 2.189 & $\underset{\substack{\infty \\
\stackrel{\sim}{N}}}{ }$ & 2.08 & $\begin{array}{c}\text { Yamalo- } \\
\text { Nenets AO }\end{array}$ \\
\hline $\begin{array}{c}\text { Tuva } \\
\text { Republic }\end{array}$ & 今े & 2.02 & ڤ̂م & 1.832 & $\begin{array}{l}\text { N } \\
\infty \\
\text { ஸ } \\
-1\end{array}$ & 2.099 & $\begin{array}{l}\infty \\
\stackrel{\infty}{N} \\
\text { N }\end{array}$ & 2.212 & $\stackrel{\text { L }}{\stackrel{N}{N}}$ & 2.121 & 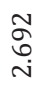 & 2.798 & $\begin{array}{l}\text { 뉴 } \\
\text { ก }\end{array}$ & 3.027 & $\underset{\stackrel{q}{+}}{\stackrel{q}{m}}$ & 3.35 & $\underset{⿱ 亠 䒑 十}{\stackrel{+}{*}}$ & 3.485 & $\begin{array}{l}\infty \\
\infty \\
m \\
m\end{array}$ & 3.35 & $\begin{array}{c}\text { Tuva } \\
\text { Republic }\end{array}$ \\
\hline $\begin{array}{l}\text { Republic of } \\
\text { Sakha }\end{array}$ & $\begin{array}{l}\infty \\
\infty \\
\infty \\
- \\
-\end{array}$ & 1.802 & 옹 & 1.771 & $\stackrel{0}{\stackrel{0}{\hat{N}}}$ & 1.847 & $\begin{array}{l}\text { Ln } \\
\infty \\
-\infty \\
-i\end{array}$ & 1.905 & $\underset{\mathfrak{m}}{\stackrel{\sim}{r}}$ & 1.724 & $\begin{array}{l}\text { ஜ̊ } \\
\text { ஜุ }\end{array}$ & 1.901 & Nิ & 1.998 & $\begin{array}{l}\hat{\text { Lิ }} \\
\text { ஸे }\end{array}$ & 2.166 & $\begin{array}{l}\infty \\
\substack{+\sim}\end{array}$ & 2.247 & $\stackrel{\vec{\sigma}}{\stackrel{\omega}{i}}$ & 2.09 & $\begin{array}{c}\text { Republic of } \\
\text { Sakha }\end{array}$ \\
\hline $\begin{array}{c}\text { Kamchatka } \\
\text { region }\end{array}$ & $\underset{\sim}{ָ}$ & 1.27 & $\underset{\overbrace{}}{\stackrel{-}{\sim}}$ & 1.195 & 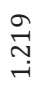 & 1.372 & $\underset{\sim}{\stackrel{+}{-}}$ & 1.423 & 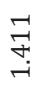 & 1.418 & $\begin{array}{l}\text { L } \\
\text { ț } \\
-i\end{array}$ & 1.518 & $\begin{array}{l}\text { 오 } \\
\text { ํำ } \\
\text { ำ }\end{array}$ & 1.512 & تై & 1.725 & $\stackrel{n}{\stackrel{n}{r}}$ & 1.85 & $\begin{array}{l}\widehat{\infty} \\
\infty \\
\stackrel{+}{-}\end{array}$ & 1.89 & $\begin{array}{c}\text { Kamchatka } \\
\text { region }\end{array}$ \\
\hline $\begin{array}{l}\text { Magadan } \\
\text { region }\end{array}$ & $\underset{\sim}{\stackrel{\sim}{+}}$ & 1.296 & $\underset{ }{\stackrel{-}{\sim}}$ & 1.25 & $\stackrel{\substack{\infty \\
\sim}}{-}$ & 1.368 & ঙ̃ & 1.433 & 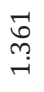 & 1.321 & 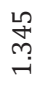 & 1.352 & 章 & 1.438 & 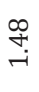 & 1.649 & 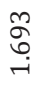 & 1.659 & 离 & 1.6 & $\begin{array}{l}\text { Magadan } \\
\text { region }\end{array}$ \\
\hline $\begin{array}{l}\text { Sakhalin } \\
\text { region }\end{array}$ & $\begin{array}{l}\text { 엄 } \\
\stackrel{-}{-}\end{array}$ & 1.229 & $\begin{array}{l}\stackrel{+}{7} \\
\stackrel{\sim}{-}\end{array}$ & 1.211 & $\underset{\sim}{\stackrel{్}{+}}$ & 1.315 & స్ & 1.449 & $\underset{\stackrel{\sim}{*}}{\stackrel{\sim}{-}}$ & 1.399 & $\underset{-}{\stackrel{\infty}{+}}$ & 1.565 & 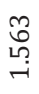 & 1.561 & 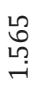 & 1.713 & $\begin{array}{l}\infty \\
\infty \\
\infty \\
-1 \\
-1\end{array}$ & 1.962 & $\begin{array}{c}\stackrel{\sigma}{\sigma} \\
\stackrel{\sim}{v}\end{array}$ & 2.16 & $\begin{array}{l}\text { Sakhalin } \\
\text { region }\end{array}$ \\
\hline Chukotka AO & $\stackrel{\infty}{+}$ & 1.655 & ֻே & 1.581 & $\begin{array}{l}\mathscr{m} \\
\infty \\
\stackrel{-}{r}\end{array}$ & 1.704 & $\begin{array}{l}m \\
\infty \\
\stackrel{-}{r}\end{array}$ & 1.99 & హ̆ & 1.782 & 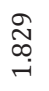 & 1.75 & 常 & 1.888 & 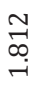 & 1.967 & ๖̊ & 2.041 & م̂ & 2.11 & Chukotka AO \\
\hline
\end{tabular}

Pro-family demographic policy allowed to prolong positive trends of birth rate of the population in Russia already in conditions of began in 2010-2011 deterioration of structure of the women in fertile age. It contributed to the realization the reproductive attitudes of population and increasing the average number of children in the families. In the period of its realization some qualitative characteristics of birth rate improved. But, on the other hand, the measures of demographic policy led to the 
compression of the calendar of births and premature depletion of the final fertility of real generations, because women in fertile age realized their reproductive intentions in more short terms to take the advantage to use the federal maternity capital, the time of its action is limited to 2018, and the regional measures, which in most regions also have a temporary character.

In 2016 in Russia after two years of stagnation the obvious decreasing of birth rate was happened. Apparently, the factor of deterioration the age structure already appeared stronger than behavioral factor, weakening in condition of conservation on equal level the pro-family demographic policy. If in the nearest time the new measures not be applied, Russia, including its northern regions, will expects long enough period of declining the birth rate level, determined by ongoing deterioration of age structure and the effect of depletion of the final fertility of real generations, which in the moment of modern demographic policy realization were in the reproductive ages.

\section{References}

1. Federal State Statistics Service [e-resource]. Available at: http://www. gks.ru.

2. Popova LA (2016) Modern Russian demographic policy in the field of fertility: results and areas for improvement // Economic and social changes: facts, trends, forecast. 2(44): pp. 79-93.

3. Shishkina MA, Popova LA (2017) Impact of modern pro-family demographic policy on birth rate intensity in the northern regions of Russia // Economic and social changes: facts, trends, forecast. 1(49): pp. 161-177.

4. Kuchmaeva OV (2010) Opportunities of statistics in the evaluation of the effectiveness of social projects // Statistics and economics. 5: pp. 96-103.

\section{Your next submission with Juniper Publishers will reach you the below assets}

- Quality Editorial service

- Swift Peer Review

- Reprints availability

- E-prints Service

- Manuscript Podcast for convenient understanding

- Global attainment for your research

- Manuscript accessibility in different formats

( Pdf, E-pub, Full Text, Audio)

- Unceasing customer service

Track the below URL for one-step submission https://juniperpublishers.com/online-submission.php 